\title{
The Success Factors of Small Business
}

Submitted 21/08/19, 1st revision 18/09/19, 2nd revision 27/10/19, accepted 20/11/19

\section{Makarenko E.N., ${ }^{1}$ Chernysheva Yu.G., ${ }^{2}$ Polyakova I.A., ${ }^{3}$ Makarenko T.V. ${ }^{4}$}

\begin{abstract}
:
Purpose: Small businesses in the economy of any country are of great significance. However, their viability is much lower than large and even medium ones. As is known, only a little number of the established small enterprises will not go bankrupt in a year, and they will succeed and continue developing for the next five years by expanding their activities. Even a smaller number of small enterprises will be able to transform into the medium one. Therefore, it is necessary to investigate the factors that assist to define the success of small businesses' performance and development.

Design/Methodology/Approach: This commentary note studies, identifies and generalizes the success factors of small enterprises described in the works of many successful entrepreneurs both in Russia and abroad. The authors use the toolkit and methods of economic analysis, consider quantitative and qualitative characteristics and features of small business development as well as entrepreneurial abilities that allow to identify key factors for small businesses' success.
\end{abstract}

Findings: The authors have found that many successful entrepreneurs describing their experience in managing business and identifying main success factors of small businesses have similar opinions in this area. These main aspects have been identified.

Practical Implications: The note provides practical recommendations to entrepreneurs establishing their small businesses and trying to develop them successfully. It describes main secrets of business and philosophies of entrepreneur's actions.

Originality/Value: The authors' position is because business success is achieved by people who have not only the necessary economic knowledge but also those who have the necessary mindset, so called philosophy of success, personal attitude including intuition.

Keywords: Small business, entrepreneurship, success factors of small business, philosophy of small business success.

JEL code: $L 26$.

Paper Type: Commentary note: Small Business.

\footnotetext{
${ }^{1}$ Professor of Rostov State University of Economics (RINH), Rostov-on-Don, Russian Federation,9034346997@mail.ru

${ }^{2}$ Professor of the Chair of business performance analysis and forecasting, Rostov State

University of Economics (RINH), Rostov-on-Don, Russian Federation, julia282001@mail.ru

${ }^{3}$ Professor of the Chair of statistics, econometrics and risk assessment, Rostov State

University of Economics (RINH), Russian Federation, migran@ rambler.ru

${ }^{4}$ Senior Tutor of accounting Chair, Rostov State University of Economics (RINH).
} 


\section{Introduction}

Many entrepreneurs, both beginners and already involved in business, often wonder what small business' success depends on. As is known, most small businesses close after the first year and only approximately 5-10\% of businesses survive in five years. Nevertheless, some businessmen become successful and turn their business into medium and even large enterprises. The development of small business depends not only on external conditions but, mostly, on the personality of a businessman because under the same conditions some entrepreneurs develop their business successfully while others go bankrupt (Kambey et al., 2018; Sycheva et al., 2018).

A lot of books are written about the elements for small business success, however, there is no single point of view on the factors predetermining the success. The wish to start a business and a skill to take risk are called more often as elements for successful business. However, those who have followed these principles have gone bankrupt even though one cannot achieve success without risk. In addition, thorough market assessment is considered as a necessary element for success. For instance, there is a lack of a shop or a service enterprise in an area. Taking up this niche, an entrepreneur may get significant income and develop his success by setting up a chain of small enterprises. Nevertheless, despite their importance even these factors may not result in establishing successful and developing business (Havlicek et al., 2013; Breckova and Havlicek, 2013).

\section{Analysis of Russian Small Business Conditions}

The development of the economy in one or another region mostly depends on the activity of small and medium business entities. Small and medium enterprises are one of the basic factors for economic growth of the real economy promoting the increase in employment. It is necessary to study the dynamics of the number of small businesses as it reflects favorable and unfavorable conditions for their existence. According to the data of Federal Tax Service of Russia the analysis of small business was carried out in 2019 as presented in Table 1.

Table 1. Analysis of the dynamics of small business (2016-2019) (OFD, 2019)

\begin{tabular}{|l|l|l|l|l|}
\hline Indexes & 10.09 .2019 & 10.09 .2018 & 10.09 .2017 & 10.09 .2016 \\
\hline $\begin{array}{l}\text { 1. The total number of } \\
\text { small and medium } \\
\text { enterprises*, items, incl. }\end{array}$ & 5.813 .278 & 5.921 .287 & 5.695 .609 & 5.671 .909 \\
\hline - microbusinesses & 5.570 .745 & 5.648 .488 & 5.409 .226 & 5.380 .768 \\
\hline - small businesses & 225.556 & 253.780 & 266.148 & 270.540 \\
\hline - medium businesses & 16.977 & 19.019 & 20.235 & 20.601 \\
\hline
\end{tabular}

Note: * the number of SME including individual entrepreneurs and legal entities.

Table 1 shows that the total number of microbusinesses increased insignificantly from 2016 till 2018, and there is a steady decline in 2019. Thus, the total number of small 
businesses decreased by $4.4 \%$ from 2016 to 2018 and the number of microbusinesses rose by $4.9 \%$. In 2019 the total number small businesses decreased by $1.8 \%$ while the number of microbusinesses decreased by $1.4 \%$. It should be noted that the number of small businesses is decreasing in 57 subjects of the Russian Federation according to the Federal Tax Service.

The feature of small business in Russia is that it is generally represented by microbusinesses with not more than 15 employees. The share of microbusinesses is extremely high. Over four studied years it has not changes significantly (it tends to grow further) and accounts for about $95.8 \%$ in 2019. Accordingly, the share of small enterprises accounts for $3.9 \%$ and the share of medium enterprises accounts for $0.3 \%$.

Figure 1. Dynamics of SME (Compiled by the authors on the data of OFD, 2019)

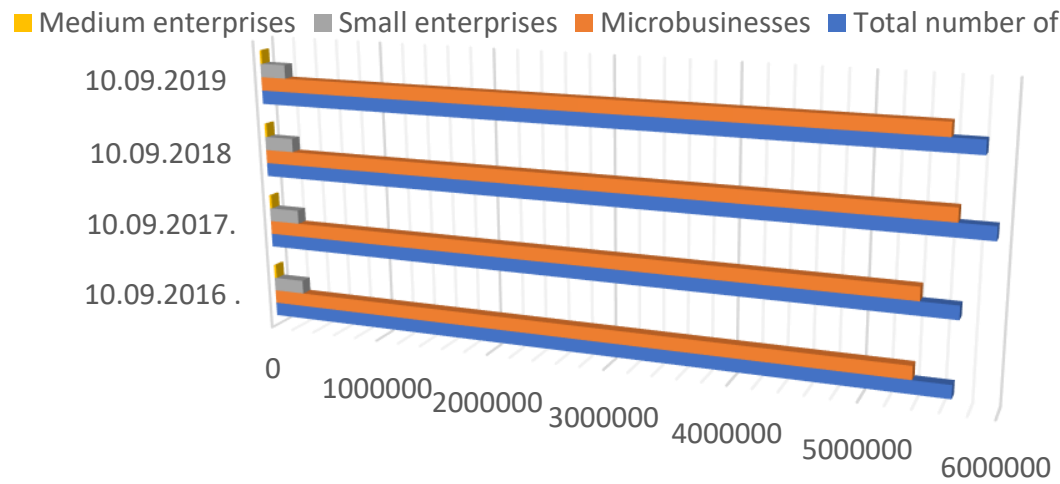

Table 2. Analysis of small business dynamics for 2019 (OFD, 2019).

\begin{tabular}{|l|l|l|l|l|l|}
\hline Indexes & 10.01 .2019 & 10.03 .2019 & 10.05 .2019 & 10.07 .2019 & 10.09 .2019 \\
\hline $\begin{array}{l}1 . \text { The total } \\
\text { number of small } \\
\text { and medium } \\
\text { enterprises*, } \\
\text { items, incl. }\end{array}$ & 6.041 .195 & 6.107 .774 & 6.184 .204 & 6.212 .137 & 5.813 .278 \\
\hline - microbusinesses & 5.771 .626 & 5.839 .974 & 5.918 .454 & 5.949 .712 & 5.570 .745 \\
\hline - small businesses & 250.758 & 249.097 & 247.133 & 244.048 & 225.556 \\
\hline $\begin{array}{l}\text { - medium } \\
\text { businesses }\end{array}$ & 18.811 & 18.703 & 18.617 & 18.377 & 16.977 \\
\hline
\end{tabular}

Note: * the number of SME including individual entrepreneurs and legal entities.

According to the analyzed data, in the summer of 2019 there was a sharp tendency to decrease the number of small enterprises. According to the register of the Federal Tax Service, 6,04 million subjects of small and medium-sized businesses have been registered in Russia by January 10, 2019 that is only $0.03 \%$ more than a year earlier. The temporary growth of small businesses (in the amount of $0.03 \%$ ) was due to the increase in the number of microbusinesses with no more than 15 employees and whose 
annual income is no more than 120 million rubles. At the same time, their number decreased by $3.5 \%$ in 9 months of 2019 .

The number of small and medium enterprises decreased by $10.0 \%$ and $9.7 \%$, respectively, in the first 9 months of 2019. The employment statistics in this sector is also unfavorable. In January 2019, 15,87 million people worked for small enterprises. Their number decreased by $2.8 \%$ in the first 9 months of 2019 .

Table 3. Dynamics of newly created microbusinesses (Compiled by the authors on the data of OFD, 2019)

\begin{tabular}{|l|l|l|l|l|}
\hline Indexes & 10.09 .2019 & 10.09 .2018 & 10.09 .2017 & 10.12 .2016 \\
\hline $\begin{array}{l}\text { The total number of } \\
\text { newly created } \\
\text { microbusinesses, incl. }\end{array}$ & 801.724 & 851.269 & 787.441 & 1.043 .349 \\
\hline $\begin{array}{l}\text { - individual } \\
\text { entrepreneurs }\end{array}$ & 585.121 & 599.630 & 484.927 & 591.871 \\
\hline - legal entities & 216.603 & 251.639 & 302.514 & 451.478 \\
\hline
\end{tabular}

According to Table 3, the number of newly created microbusinesses has been steadily declining over the past four years. In 2019 the total number of microbusinesses decreased by $23.2 \%$ compared to 2016 . The number of individual entrepreneurs decreased by $1.1 \%$ during the same period, and the number of legal entities decreased by $52.0 \%$. According to the Federal State Statistic Service, the share of small and medium businesses in the Russian economy was $21.9 \%$ (more than 20 trillion rubles) in 2017. In 2014 the contribution of small and medium businesses to the economy accounted for 19\%, in $201519.9 \%$, and in $201621.6 \%$.

Comparing to the same index of the European countries is much lower than half. Thus, according to the Growth Economy Institute the share of small and medium enterprises in the GDP of European countries accounts for 50-60\%. For instance, in Great Britain it is $51 \%$, in Germany $53 \%$, in Finland 60\%, in the Netherlands 63\%. According to the data of MAGRAM Market Research - the Independent Full-Cycle Research Agency (2019) in the third and fourth quarters of 2018, the Small and Medium Business Index (RSBI) dropped below 50 points to 47.1 points, compared to 48.5 . In general, the indicator has been declining since the second half of 2018. It can be said that currently small business in Russia is in recession. All these data show that small businesses have not been developing in Russia for several years, and in the last year, there has been an unfavorable tendency to decrease the number of small enterprises. At the beginning of 2019 entrepreneurs were pessimistic about their own business and economy, and business expectations were the worst in the last five years. Among other reasons we consider the following:

$>$ the fall in incomes of the population during the last five years as a result of the economic crisis;

$>$ the increase in tax burden over the last year; 
$>$ the lack of improvement in the business climate;

$>$ the strengthening of the influence of federal networks that "take the market" of small enterprises.

\section{The Study of "the Portrait of a Russian Entrepreneur"}

In Russia, under the conditions of the small business recession, MAGRAM conducted a study of the so-called portrait of a Russian entrepreneur in the second quarter of 2019. The total number of owners and managers taking part in the study are 2300 small and medium enterprises from 23 regions of the Russian Federation where is $63 \%$ of all Russian companies from SME segment. The entrepreneurs themselves were studied: what they did before establishing their first own business, what funds they used while opening a business, what working hours they have etc. According the results of the research for $80 \%$ of entrepreneurs, the businesses they currently own is the first. $20 \%$ were already owners or co-owners of other enterprises. According to the area of the activity (trade, production, services) these figures are almost the same: trade $18 \%$, production $22 \%$, services $22 \%$.

Only 5\% of entrepreneurs founded their businesses immediately after their studying or the mandatory service in the army. In addition, the biggest share of 'graduates' is in trade $(10 \%)$, and the smallest one is in services $(2 \%)$. The share in production accounts is $6 \% .28 \%$ of respondents went into their business from the position of directors and senior managers in other organizations. More than half of entrepreneurs opened their first business on their own savings (58\%), $20 \%$ of respondents borrowed money from relatives and acquaintances, and $15 \%$ of businessmen combined their capital with the partner. $14 \%$ of businessmen took advantage of bank credit. The family members of only $42 \%$ of businessmen take part in their businesses, in most cases they either help unofficially $(17 \%)$ or are employees $(10 \%)$. Family members become co-owners of the businesses only by $42 \%$. The family members of $48 \%$ respondents do not take any part in the business.

Figure 2. The share of family members' involvement in business

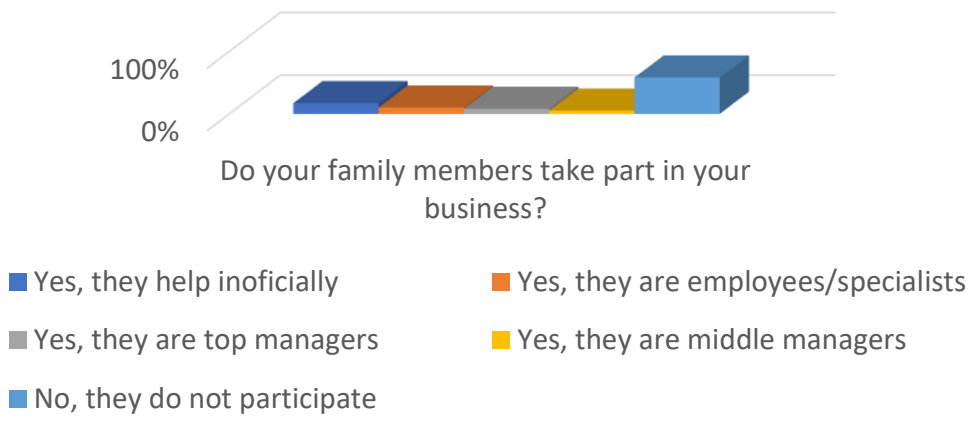

Moreover, $42 \%$ of businessmen would not like their children to develop their business. Among them, the highest share belongs to the owners of trading companies (47\%), 
and the lowest (29\%) to the owners of production enterprises. 57\% of respondents answered negatively to the question "Would you change your current business for employment if your income remained the same?" (where the owners of production enterprises account for $61 \%$ ). $21 \%$ of business owners (one fifth of all respondents) would agree to become an employee again. The share of the businessmen in trade area is the highest and accounts for $25 \%$.

Figure 3. The share of entrepreneurs ready to change their business for employment

Would you change your current business for employment if your income remained the same?

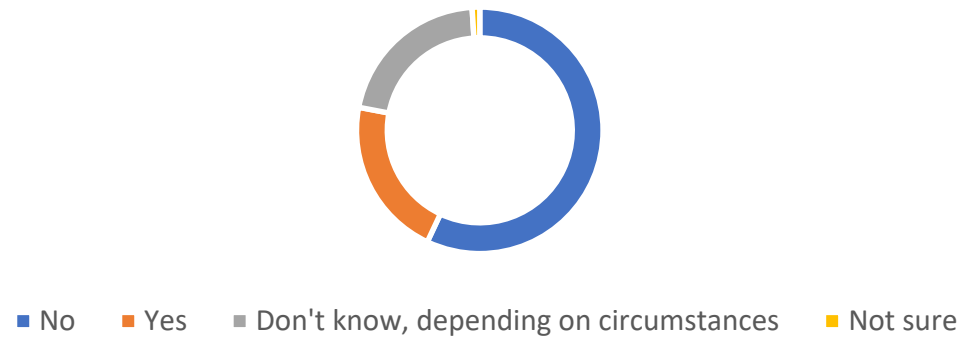

\section{Key Elements for Small Business Success}

Small businesses are important for any economy. At the same time, its viability is much lower than large and even medium businesses. As it was noted, only a small share of newly formed small enterprises will not break down in the first year, but it will be successful and can develop in the next five years, expanding their activities (Chernysheva and Shepelenko, 2017). Even fewer small businesses can move into the category of middle ones. Why is this happening? Many researchers looking into the success factors of small business, skills which successful entrepreneurs have, identify the following positions:

- Energy: Business needs constant movement, desire to grow and develop;

- Risk ability: Risk is an integral part of business and without it business cannot exist;

- Complete immersion in business: Successful entrepreneurs live with their business, they always live in them, they do not have working hours, they have no holidays and days off;

- Deep knowledge of business processes: To succeed in anything, you need to understand all the subtleties of your business (for example, where you can have the greatest costs, or where you can fool your employees). Without this, it is almost impossible to achieve serious success in business.

Many successful entrepreneurs describing their experience in conducting a business identify the same success factors of small business and have similar opinions in this 
area. Due to this fact, it is interesting to study success factors of business mentioned by the entrepreneurs themselves.

Thus, having analyzed Henry Ford's experience one can point out that he defined the store of knowledge, experience and opportunities as the main factor. John Rockefeller considered the use of innovations, the use of something new and not used by others as the ground for success. It will allow to become a leader. Sam Walton, the creator of the American chain of stores Wal-Mart, maintained the same point of view. He believed it was necessary to come up with an idea and give all forces to its implementation. He anticipated the format of modern hypermarkets and introduced special rules that are strictly followed to nowadays. For example, he consciously reduced prices (in those times it was a revolutionary decision), arranged great sales and discounts, introduced self-service buyers wander about the store, filling baskets and trolleys, used the "product of the day" (every day - a discount on any commodity).

In his book "Think big and kiss ass in business and life!" D. Trump underlines that "a part of the winning strategy is understanding when it is enough. Sometimes you will have to abandon the fight, leave it and move on to something more productive". He notes that success and wealth are achieved by the strong, and failures in business are for the weak. D. Trump formulates the secrets of business success: passion and sound anger, that is, everyone determines what work gives him pleasure; a real look at the world and creativity to solve business problems; forget the word "no"; learn to elbow through and respond with a blow to the blow; never give up and it is always necessary to think ahead in the business. D. Trump is practicing a strategy of broad-based thinking - that is the content of his business success philosophy." No one will hold you by hand or help you. You take this fight alone. And you should be able to bend, but not break under any circumstances" (Trump, 2009).

Russian businessman O. Tinkov (the founder of the chain of stores of household appliances "Technoshok", factories "Daria", brewery and restaurant chain "Tinkoff") also notes the need for self-sufficiency, focus on business, confidence and professionalism among the obligatory success factors.

In his book "The making of McDonald's" Ray Krock, one of McDonald's founders, tells about some secrets of business success. These include optimizing and automating business processes and contributing to the training of employees, even the most ordinary employees (Krock and Anderson, 2016). Other successful businessmen, such as John Shaul (an American specialist in culture service area, a founder and president of the Service Quality Institute), has a similar point of view. He is sure that employees should be invested, motivated, trained. Tony Shay, an expert in the SEU promotion of the Zappos.com online store, also believes, that successful business requires a competent staff selection. M. Rybakov (business consultant and the owner of company "Mikhail Rybakov and partners") underlines the importance of automation of business processes as one of success factors in business. That is, we are talking about the abandonment of "chaotic management" and the transition to a "transparent" system 
that allows the company to work effectively and purposefully for the result and do everything to implement it.

Jeff Bezos (Amazon's chief executive and one of the richest people on the planet) also notes that the secret to its success is its ability to retain its customers. His words reflect this approach: "The most important rule of an entrepreneur is to focus on customers. Our goal is to become the most client-oriented company in the world".

Taking into account the above opinions of successful entrepreneurs and based on the research, it can be said that the main feature of successful entrepreneurs is the peculiarities of thinking - as a rule, these are very confident people who have developed skills of social communication and easily make decisions (Shepelenko and Chernysheva, 2018). Those wishing to become entrepreneurs are mistakenly waiting for ideal conditions to start their project: they quit from work, they wait out the crisis etc. A successful businessman understands that a favorable moment for opening his business can never come, so you can start business at any time.

\section{Conclusion}

Summarizing all the above points of view on the main factors of business success expressed by successful entrepreneurs and considering that all of them have different levels of education and personal qualities, it can be said that success in business is achieved by people who have not only the necessary volume of economic knowledge about its management, but also possessing the necessary mentality, so-called philosophy of success, personal mood including intuition. In our opinion, there can be identified several elements that all successful businessmen mention:

1. In-depth knowledge of the subject area of your business. The entrepreneur must know the whole process of creating his product to understand where "bottlenecks" can be in order to be able to prevent their occurrence. At the same time, it is necessary to develop and learn constantly, which will allow to expand the outlook, to understand better oneself and your product, consumers and competitors.

2. A clear goal for your business. It is necessary to imagine what and how will be produced, what is the strategy of business development both for the short-term and for the long-term period. At the same time, the entrepreneur must have a real interest in his business, energy and perseverance for the fulfillment of his ideas.

3. Innovative ideas are needed to help make your business special, bring it a unique experience, unlike competitor's one. One of the modern trends is the orientation toward customers, their needs, desires. Many entrepreneurs started form unique ideas in this field.

4. Creating a system business that involves transparency of its business processes on the one hand, and on the other hand - business processes should be clearly established 
(for example, competent planning, no "superfluous" actions, the presence of key performance indicators of each employee or department, automation of the work of employees), which will help to work for the result. In addition, the system will allow the owner to withdraw from operational regulation later and delegate many of his functions to other employees.

5. Competent staff selection and their further obligatory development, training, creating the favorable working conditions.

6. Business needs realism (setting goals, assessing the situation and opportunities, overcoming failures, etc.) and readiness for change (different maneuvers, constant renewal of business will be required for business development. If you do not change your business, the market will change and leave the entrepreneur isolated).

It can be said that the given success factors may be useful for entrepreneurs establishing their small business and trying to develop it successfully as it allows to take an advantage over competitors.

\section{References:}

Brecková, P. and Havlícek, K. 2013. Leaders Management and Personnel Controlling in SMEs. European Research Studies Journal, 16 (4), Special Issue on SMEs.

Chernysheva, J.G., Shepelenko, G.I. 2017. Analysis of Moral-and-Ethic Business in Russia. European Research Studies Journal, 20(S1), 311-318.

Havlícek, K., Thalassinos. I.E. and Berezkinova, L. 2013. Innovation Management and Controlling in SMEs. European Research Studies Journal, 16(4), 57-70, Special Issue on SMEs.

Kambey, J.P., Wuryaningrat, N.F., Kumajas, L.I. 2018. Examining leadership and knowledge sharing role on small and medium enterprises innovation capabilities. International Journal of Economics and Business Administration, 6(1), 24-38.

Krock, R., Anderson, R. 2016. The making of McDonald's. Alpina publisher.

Magram. 2019. Magram market research. Available at: http://www.magram.ru

OFD. 2019. Data of Federal Tax Service of Russia. Available at: https://ofd.nalog.ru/statistics.html

Shepelenko, G.I., Chernysheva, Yu.G. 2018. Features and problems of managing the strategy of small business development. Modernization of business systems of regions of Russia as a factor of economic growth: Trends, challenges, models and prospects. Rostov-on-Don.

Sycheva, I.N., Ovchinnicov, Y.L., Voronkova, O.Y.U., Akhmetshin, E.M., Kolmakov, V.V., Vasilieva, A.G. 2018. Economic potential and development prospects of small businesses in rural areas. European Research Studies Journal, 21(4), 292-303.

Trump, D. 2009. Think big and kiss ass in business and life! $2^{\text {nd }}$ edition, Moscow, Alpina business books, 22-34. 